\title{
Integrating Indigenous Ecological Knowledge and Science in Natural Resource Management: Perspectives from Australia
}

\author{
Erin L. Bohensky $^{l}$, James R. A. Butler $^{l}$ and Jocelyn Davies ${ }^{l}$
}

Key Words: Australia; indigenous knowledge; knowledge integration; natural resource management; resilience

Ecology and Society's 2004 special feature on Traditional Knowledge in Social-Ecological Systems (http://www. ecologyandsociety.org/issues/view.php/feature/13) marked one of the first efforts to view traditional, local, and Indigenous knowledge and their roles in managing ecosystems through the lens of social-ecological systems (SES) resilience. This view acknowledges the importance of experimentation, learning, and pluralism to cope with uncertainty in complex adaptive systems (Folke 2004, Folke et al. 2005, Berkes and Turner 2006, Davidson-Hunt 2006, Berkes 2009). As a frame for understanding knowledge, SES resilience provided new inspiration for scientists seeking to understand Indigenous livelihoods and resource management, increasingly against the backdrop of rapid global change (Armitage and Johnson 2006, Mercer et al. 2012, Raygorodetsky 2013).

Yet, we observed a remarkable void in the 2004 special feature and in SES resilience scholarship more generally: experience from Australia was largely absent, despite this country's extraordinary indigenous cultural diversity and innovative research at the interface of indigenous and conventional science knowledge in a variety of traditions (Jones 1969, Newsome 1980, Kimber 1984, Burbidge et al. 1988, Burrows and Christensen 1990, Christie 1990, Walsh 1990, Jones 1991, Baker and Mutitjulu Community 1992, Williams and Baines 1993, Bomford and Caughley 1996, Raymond et al. 1999, Horstman and Wightman 2001, Howitt 2001). With this Special Feature we strive to further understanding of theory and practice for integration of Indigenous Ecological Knowledge (IEK) and conventional science relevant to the Australian context. We aim to: 1) examine examples of knowledge integration in Australia; 2) understand conditions and enabling environments for knowledge integration; 3) suggest processes and tools for practically achieving knowledge integration.

Current measures of well-being largely continue to ignore that the relationship between ecosystems and well-being is more direct, complex, and fundamental to indigenous ontologies than for mainstream Australian society (Sangha et al. 2011). Decoupling of intimate relationships between Indigenous groups and their lands and "sea country" (deKoninck et al.
2013) and erosion of much of the depth and detail of IEK has been one consequence. Australian indigenous communities continue to face great disadvantage arising from a complex web of historical and contemporary social and environmental pressures (Moran 2009, Sutton 2009, Wohling 2009). The conjunction of densely connected kinship networks, historical exclusion from access to resources, and coercive external interventions has generated codependent rigidity and poverty traps (Maru et al. 2012). At a psychological level, structural and cultural violence (Galtung 1969, 1990) from colonialism and its legacies has driven some Indigenous people to adopt disadvantage as part of their identity, and to fear that improvements in material circumstances will necessarily be accompanied by loss of culture or identity (Pholi 2012).

Conversely, integration of Indigenous knowledge and science has been accelerating in recent years, as part of a marked recoupling of Indigenous relationships with traditional lands and sea country throughout Australia. Indeed, the increased formal involvement (e.g., through participation in forums, bodies and implementation processes) of indigenous Australians in natural resource management (NRM) has been noted as one of four standout trends in environmental management in the first decade of the $21^{\text {st }}$ century (Australia State of the Environment Committee 2011:9). Such settings form the context of most of the papers in this Special Feature. Policy drivers for increased formal involvement have included the sheer extent of indigenous landholdings that has resulted from government actions since the 1960s to recognize indigenous land rights. Biodiversity and other environmental values ascribed to these lands by nonindigenous people (see Davies et al. 2013), along with the low financial capital and lack of employment or enterprise opportunities amongst landowners, has driven government investment in indigenous environmental management. Other ultimate causes include international instruments, notably the Convention on Elimination of All Forms of Racial Discrimination and the Convention on Biological Diversity's Article 8(j); and belated legal recognition since 1992 that indigenous native title survived colonization of Australia and continues to exist in some circumstances (Nettheim and Craig 2002). 
Knowledge integration has been noted as problematic, often because of disparate power relations (e.g., Nadasdy 1999, Wohling 2009). Tensions arise in part because the term is used in various ways, often loosely, such that its meaning is unclear. The common definitions of integration as 'combining one thing with another to form a whole', and, in social contexts, as the 'intermixing of people or groups previously separated', can readily subvert another important dimension of meaning: that the outcome of such processes is equal participation (Oxford English Dictionary and New Oxford American Dictionary). Each paper in this Special Feature has been concerned with the integrity of indigenous knowledge in integration processes. This has undoubtedly been strengthened by the involvement of indigenous people as authors and coresearchers in the research reported herein: of the 36 contributing authors, nine are Indigenous.

Many of the papers specifically highlight that the use and management of knowledge is a situated social process in which indigenous people interface with more powerful actors. Such settings are central to how the meaning of integration has been critically understood in broader social contexts: as the appropriate strategy for nondominant groups to engage in when they seek to maintain relationships with larger society, and to maintain their own identity and characteristics (Berry 1997). In Berry's (1997) framework, integration contrasts with assimilation, which does not maintain distinctive cultural identities in a nondominant group's interactions with broader society; and with separation, which maintains distinctive cultural identities without broader social interaction. Further, the mutual accommodation required to achieve integration includes widespread acceptance of the value of knowledge diversity for NRM by both nondominant and dominant groups. Absence of such conditions precipitates marginalization because nondominant groups have no interest in engaging with dominant institutions, which may enforce cultural loss (Berry 1997).

Notwithstanding the trend to increased formal involvement of Indigenous people in Australian environmental management, several papers note that lack of integration between IEK and conventional science knowledge was a starting point for their contributions. For example, Prober et al. (2011) draw attention to inadequate cross-cultural means to communicate IEK as limiting achievement of knowledge integration in NRM. Davies et al. (2013) recount how the first generation of management plans for Indigenous-owned and managed protected areas maintained distinctions between nature and society, which are characteristic of dominant Australian ontologies but the antithesis of Indigenous world views. Gratani et al. (2011) note that traditional owners in their study considered that NRM decisions do not always respect their cultural values or IEK, despite their comanagement role in their traditional country. Robinson and Wallington (2012) note that differences in the values of Indigenous peoples and
Kakadu National Park managers towards feral animals, and the absence of knowledge integration in decision-making, has driven recent cross-cultural tensions. Walsh et al. (2013) suggest that little of the richness and interconnected understandings inherent in Arrernte ecological knowledge has been engaged in projects which claim to have complemented science knowledge of land and species.

The contribution that the Special Feature's papers makes to our three aims has ultimately been determined by their specific contexts, guiding questions and methods. Examples of knowledge integration in Australia, our first aim, are presented most directly in three papers: Hill et al. (2012) synthesize features of indigenous engagement in environmental management where IEK and science are being integrated, and others where there is little or no integration. Butler et al. (2012) found that government managers and scientists considered IEK had been applied in management of four of seven fisheries in Torres Strait, and describe the types of knowledge concerned; and Davies et al. (2013) examine recent management plans for Indigenous Protected Areas (IPAs), which have integrated the ontologies and governance systems of Indigenous landowners with conservation objectives.

Several papers contribute particularly to our second aim: understanding conditions and enabling environments for knowledge integration. Bohensky and Maru (2011) reviewed selected international literature to distill lessons learned from integration efforts over the past decade. Themes that they identify resonate with lessons emerging in Australia, including the benefits and challenges of integrating IEK (Prober et al. 2011, Holmes and Jampijinpa 2013, Walsh et al. 2013); recognizing the social context of IEK (Hill et al. 2012, Holmes and Jampijinpa 2013, Walsh et al. 2013); and evaluating IEK and the degree of integration (Gratani et al. 2011, Butler et al. 2012).

Notably, this social context includes power relations. For example, Butler et al. (2012) consider the roles of depleted fishery stocks, limited scientific knowledge, and community ownership of resources in the application of TEK in the Torres Strait Islands. They find that unlike other Melanesian regions (Johannes 1998, Johannes 2002), these factors do not determine the application of IEK in fisheries, and instead the evolutionary stage of comanagement and the degree of powersharing is more influential. They also find the concept of cultural keystone species (Garibaldi and Turner 2004) valuable in explaining why knowledge integration is more evident in fisheries for species with highest cultural values, and how this has catalyzed IEK application more widely.

Conditions and enabling environments for knowledge integration are discussed by Hill et al. (2012) on the basis of a typology of Indigenous engagement in NRM. They note that the distinction between IEK and conventional science is blurred in Indigenous-led collaborations, and these 
governance types were found to be maintaining the integrity of IEK, and applying both sets of knowledge. In contrast, governance types where agencies have the lead role raise the threat that IEK will be misappropriated such that the Indigenous partners are more concerned with protecting their knowledge against unauthorized or ill-informed use. Concern with validating Indigenous knowledge by science is characteristic of agency-led initiatives (Hill et al. 2012). Indeed, Gratani et al. (2011) report on a process to validate Indigenous knowledge of plant-derived poisons to manage invasive fish in one region subject to such agency-led governance, the Wet Tropics World Heritage Area. Power relationships are again highlighted, with Indigenous elders' control over the validation process found to be critical to their sense of empowerment.

Our third aim, processes and tools for integrating knowledge, is noted by Bohensky and Maru (2011) as an expanding area in recent international literature. Research by Ens et al. (2012) describes a similar trend in Australia, and several papers in this Special Feature extend these contributions. Prober et al. (2011) focus on ecological calendars developed in a number of cross-cultural collaborations to organize IEK, effectively correlating climate, astronomy, resource availability, and cultural practices. They argue for calendars' potential to be more directly used as adjuncts to spatial and social frameworks for comanagement. Robinson and Wallington (2012) describe mapping and narrative tools applied to resolve uncertainties about feral animal management in Kakadu National Park. The effectiveness of knowledge integration relied on boundary agents, people with the capacity to communicate equitably across knowledge systems. Davies et al. (2013) also highlight the key role played by brokers in the development of IPA management plans that integrate knowledge.

Two papers, Walsh et al. (2013) and Holmes and Jampijinpa (2013) have resulted from deep collaborations in central Australia over many years between Indigenous and nonindigenous authors wanting to overcome ineffective presentation of IEK, so that it becomes only, as Houde (2007) cautions, "a collection of data about the environment". The papers each present their IEK frameworks as tools for crosscultural engagement and for intergenerational teaching and learning. Each framework emphasizes the interconnections between elements and domains of knowledge, including reciprocated cross-linkages between particular groups of people and particular natural resources and land areas. Through such interconnections, IEK simultaneously encompasses both what is known and who has the responsibility to know, to make decisions, to take action, and to learn. Several other papers (Gratani et al. 2011, Robinson and Wallington 2012, Davies et al. 2013) also highlight that knowledge integration is a social process that must recognize the identity of, and relationships amongst, the people whose knowledge might be integrated.
Lastly, we hoped in this Special Feature to gain insight into different dimensions of the relationship between knowledge integration and resilience, not only for the benefit of scholarship but also for global policy processes on which diverse knowledges are now being brought to bear (e.g., the Intergovernmental Platform for Biodiversity and Ecosystem Services). Reiterated is the central role of institutions that embed social and ecological linkages, diversity, empowerment, learning, and adaptive approaches. A range of perspectives is given on resilience, underscoring the richness of this framework while also highlighting that the meaning and utility of the concept varies between users and contexts. A particular challenge for advancing empirically-based understanding of how IEK builds resilience is that discussions between scientists and IEK holders around resilience, adaptation, change, and thresholds may be contentious, echoing previously-voiced concerns (Rotarangi and Russell 2009). This implies the need for careful processes, time commitments, underlying trust, and sound tools that are adaptable across social and ecological contexts. A further challenge is to identify when knowledge integration is being achieved, given the ambiguity of the term noted above, and the limited availability of evaluative measures. Herein lies a further opportunity for greater interaction between the academic, policy, and place-based stakeholders that have often been addressing knowledge integration independently.

Responses to this article can be read online at: http://www.ecologyandsociety.org/issues/responses. $\mathrm{php} / 5846$

\section{Acknowledgments:}

This special feature was made possible by the generous assistance of the communities and organisations that have collaborated in this research, as indicated in the articles herein. We thank Yiheyis Maru for constructive comments on this Introduction, as well as the reviewers who gave their time to provide feedback on other articles. CSIRO's Ecosystem Sciences Division, Climate Adaptation Flagship, Sustainable Agriculture Flagship, Wealth from Oceans Flagship and the Building Resilient Australian Biodiversity Assets Theme provided financial support to the three special feature editors. The United Nations University Traditional Knowledge Initiative and Ian Nigh are thanked for their research support. Lastly, we thank participants in the Resilience Alliance Workshop on Indigenous Resilience and Social-Ecological Systems at Hinchinbrook Marine Cove in 2009 for inspirational discussions. 


\section{LITERATURE CITED}

Armitage, D. R. and D. Johnson. 2006. Can resilience be reconciled with globalization and the increasingly complex conditions of resource degradation in Asian coastal regions? Ecology and Society 11(1): 2. [online] URL: http://www. ecologyandsociety.org/vol11/iss1/art2/.

Australia State of the Environment Committee. 2011. Australia state of the environment 2011. Independent report to the Australian Government Minister for Sustainability, Environment, Water, Population and Communities. DSEWPaC, Canberra. [online] URL: http://www.environment. gov.au/soe/2011/report/.

Berkes, F. 2009. Evolution of co-management: role of knowledge generation, bridging organizations and social learning. Journal of Environmental Management 90: 16921702. http://dx.doi.org/10.1016/j.jenvman.2008.12.001

Berkes, F., and N. J. Turner. 2006. Knowledge, learning and the evolution of conservation practice for social-ecological system resilience. Human Ecology 34: 479-494. http://dx.doi. org/10.1007/s10745-006-9008-2

Baker, L. M. and Mutitjulu Community. 1992. Comparing two views of the landscape: Aboriginal traditional ecological knowledge and modern scientific knowledge. The Rangeland Journal 14(2): 174-189. http://dx.doi.org/10.1071/RJ9920174

Berry, J. W. 1997. Immigration, acculturation, and adaptation. Applied Psychology-an International Review-Psychologie Appliquee-Revue Internationale 46: 5-34.

Bohensky, E. L. and Y. Maru. 2011. Indigenous Knowledge, Science, and Resilience: What Have We Learned from a Decade of International Literature on "Integration"? Ecology and Society 16(4): 6. http://dx.doi.org/10.5751/ES-04342-160406

Bomford, M. and J. Caughley, editors. 1996. Sustainable Use of Wildlife by Aboriginal peoples and Torres Strait Islanders. Bureau of Resource Sciences, Australian Government Publishing Service, Canberra.

Burbidge, A. A., K. A. Johnson, P. J. Fuller, and R. I. Southgate. 1988. Aboriginal knowledge of the mammals of the central deserts of Australia. Australian Wildlife Research 15: 9-39. http://dx.doi.org/10.1071/WR9880009

Burrows, N. and P. Christensen. 1990. A survey of Aboriginal fire patterns in the Western Desert of Australia. Fire and the Environment: Ecological and Cultural Perspectives, US Department of Agriculture Forest Service, General Technical Report SE-69, Southeastern Forest Experimental Station, Asheville:20-24.

Butler, J. R. A., A. Tawake, T. Skewes, L. Tawake, and V. McGrath. 2012. Integrating Traditional Ecological Knowledge and Fisheries Management in the Torres Strait, Australia: the
Catalytic Role of Turtles and Dugong as Cultural Keystone Species. Ecology and Society 17(4): 34. http://dx.doi. org/10.5751/ES-05165-170434

Christie, M. J. 1990. Aboriginal science for the ecologically sustainable future. Ngoonjook: Batchelor Journal of Aboriginal Education November 1990: 56-68.

Davidson-Hunt, I .J. 2006. Adaptive learning networks: developing resource management knowledge through social learning forums. Human Ecology 34: 593-614. http://dx.doi. org/10.1007/s10745-006-9009-1

Davies, J., R. Hill, F. J. Walsh, M. Sandford, D. Smyth, and M. C. Holmes. 2013. Innovation in management plans for community conserved areas: experiences from Australian indigenous protected areas. Ecology and Society 18(2): 14. http://dx.doi.org/10.5751/ES-05404-180214

deKoninck, V., R. Kennett, and P. Josif. 2013. National Indigenous Sea Country Workshop Report. NAILSMA Knowledge Series 014/2013. North Australian Indigenous Land and Sea Management Alliance (NAILSMA), Darwin. [online] URL: http://nailsma.org.au/hub/resources/publication/ national-indigenous-sea-country-workshop-report-2012

Ens, E.J., M. Finlayson, K. Preuss, S. Jackson and S. Holcombe. 2012. Australian approaches for managing 'country' using Indigenous and non-Indigenous knowledge. Ecological Management \& Restoration 13(1): 100-107. http:// dx.doi.org/10.1111/j.1442-8903.2011.00634.x

Folke, C. 2004. Traditional knowledge in social-ecological systems. Ecology and Society 9(3): 7. [online] URL: http:// www.ecologyandsociety.org/vol9/iss3/art7/

Folke, C., T. Hahn, P. Olsson and J. Norberg. 2005. Adaptive governance of social-ecological systems. Annual Review of Environmental Research 30: 441-473. http://dx.doi. org/10.1146/annurev.energy.30.050504.144511

Galtung, J. 1969. Violence, peace and peace research. Journal of Peace Research 6(3): 167-191. http://dx.doi. org/10.1177/002234336900600301

Galtung, J. 1990. Cultural violence. Journal of Peace Research 27: 291-305.

Garibaldi, A. and N. Turner. 2004. Cultural keystone species: implications for ecological conservation and restoration. Ecology and Society 9(3): 1. [online] URL: http://www. ecologyandsociety.org/vol9/iss3/art1/.

Gratani, M., J. R. A. Butler, F. Royee, P. Valentine, D. Burrows, W. I. Canendo, and A. S. Anderson. 2011. Is Validation of Indigenous Ecological Knowledge a Disrespectful Process? A Case Study of Traditional Fishing Poisons and Invasive Fish Management from the Wet Tropics, Australia. Ecology and Society 16(3): 25. http://dx.doi. org/10.5751/ES-04249-160325 
Hill, R., C. Grant, M. George, C. J. Robinson, S. Jackson, and N. Abel. 2012. A Typology of Indigenous Engagement in Australian Environmental Management: Implications for Knowledge Integration and Social-ecological System Sustainability. Ecology and Society 17(1): 23. http://dx.doi. org/10.5751/ES-04587-170123

Holmes, M. C. C., and W. (S. P.) Jampijinpa. 2013. Law for country: the structure of Warlpiri ecological knowledge and its application to natural resource management and ecosystem stewardship. Ecology and Society 18(3): 19. http://dx.doi. org/10.5751/ES-05537-180319

Horstman, M., and G. Wightman. 2001. Karparti ecology: recognition of Aboriginal ecological knowledge and its application to management in North-Western Australia. Ecological Management and Restoration 2: 99-109. http://dx. doi.org/10.1046/j.1442-8903.2001.00073.x

Houde, N. 2007. The six faces of traditional ecological knowledge: challenges and opportunities for Canadian comanagement arrangements. Ecology and Society 12(2): 34. [online] URL: http://www.ecologyandsociety.org/vol12/iss 2/ art34/.

Howitt, R. 2001. Rethinking resource management: justice, sustainability and indigenous peoples. Psychology Press. Routledge. London, UK.

Johannes, R. E. 1998. The case for data-less marine resource management: examples from tropical nearshore finfisheries. Trends in Ecology \& Evolution 13: 243-246. http://dx.doi. org/10.1016/S0169-5347(98)01384-6

Johannes, R. E. 2002. The renaissance of community-based marine resource management in Oceania. Annual Review of Ecology and Systematics 33: 317-340. http://dx.doi. org/10.1146/annurev.ecolsys.33.010802.150524

Jones, R. 1991. Landscapes of the mind: Aboriginal perceptions of the natural world. Pages 21-48 in D. J. Mulvaney, editor. The Humanities and the Australian Environment. Australian Academy of the Humanities, Canberra.

Jones, R. M. 1969. Fire-stick farming. Australian Natural History 16: 224-228.

Kimber, R. G. 1984. Resource use and management in central Australia. Australian Aboriginal Studies 1984: 12-23.

Maru, Y. T., C. S. Fletcher, and V. H. Chewings. 2012. A synthesis of current approaches to traps is useful but needs rethinking for indigenous disadvantage and poverty research. Ecology and Society 17(2): 7. http://dx.doi.org/10.5751/ ES-04793-170207

Mercer, J., I. Kelman, B. Alfthan, and T. Kurvits.. 2012. Ecosystem-Based Adaptation to Climate Change in Caribbean
Small Island Developing States: Integrating Local and External Knowledge. Sustainability 4: 1908-1932. http://dx. doi.org/10.3390/su4081908

Moran, M. 2009. What job, which house?: Simple solutions to complex problems in indigenous affairs. Australian Review of Public Affairs [online] URL: http://www.australianreview. net/digest/2009/03/moran.html.

Nettheim, G. M., and G. D. Craig. 2002. Indigenous peoples and governance structures: a comparative analysis of land and resource management rights. Aboriginal Studies Press, Canberra, Australia.

Newsome, A.E. 1980. The eco-mythology of the red kangaroo in central Australia. Mankind 12: 327-333. http://dx.doi. org/10.1111/j.1835-9310.1980.tb01207.x

Pholi, K. 2012. Silencing dissent inside the Aboriginal industry. Quadrant (Sydney) 56: 6-15.

Prober, S. M., M. H. O'Connor, and F. J. Walsh. 2011. Australian Aboriginal Peoples' Seasonal Knowledge: a Potential Basis for Shared Understanding in Environmental Management. Ecology and Society 16(2): 12. [online] URL: http://www.ecologyandsociety.org/vol16/iss2/art12/

Raygorodetsky, G. 2013. The Skolt Sámi's path to climate change resilience. OurWorld 2.0, 1 February 2013 [online] URL: http://ourworld.unu.edu/en/the-skolt-sami-path-to-climatechange-resilience/

Raymond, E., J. Blutja, L. Gingina, M. Raymond, O. Raymond, L. Raymond, J. Brown, Q. Morgan, D. Jackson, N. Smith, and G. Wightman. 1999. Wardaman ethnobiology. Pages 1-191. Centre for Indigenous Natural and Cultural Resource Management, Northern Territory University, Darwin.

Robinson, C. J. and T. J. Wallington. 2012. Boundary Work: Engaging Knowledge Systems in Co-management of Feral Animals on Indigenous Lands. Ecology and Society 17(2): 16. http://dx.doi.org/10.5751/ES-04836-170216

Rotarangi, S., and D. Russell. 2009. Social-ecological resilience thinking: can indigenous culture guide environmental management? Journal of the Royal Society of New Zealand 39(4): 209-213.

Sangha, K. K., J. R. A. Butler, A. Delisle, and O. Stanley. 2011. Identifying links between ecosystem services and Aboriginal well-being and livelihoods in north Australia: applying the Millennium Ecosystem Assessment framework. Journal of Environmental Science and Engineering 5: 931-946.

Sutton, P. 2009. The Politics of Suffering. Melbourne University Press, Melbourne, Australia. 
Walsh, F. J., P. V. Dobson, and J. C. Douglas. 2013. Anpernirrentye: a framework for enhanced application of indigenous ecological knowledge in natural resource management. Ecology and Society 18(3): 18. http://dx.doi. org/10.5751/ES-05501-180318

Walsh, F. J. 1990. An ecological study of traditional Aboriginal use of "country": Martu in the Great and Little Sandy Deserts, Western Australia. Proceedings of the Ecological Society of Australia 16: 23-37.

Williams, N. M. and G. Baines, editors. 1993. Traditional ecological knowledge: wisdom for sustainable development. Centre for Resource and Environmental Studies, Australian National University, Canberra.

Wohling, M. 2009. The problem of scale in indigenous knowledge: a perspective from northern Australia. Ecology and Society 14(1): 1. [online] URL: http://www. ecologyandsociety.org/vol14/iss1/art1/. 